International Journal of Instruction e-ISSN: 1308-1470 • www.e-iji.net

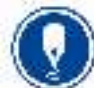

April 2021 • Vol.14, No.2

p-ISSN: 1694-609X

pp. $253-270$

Article submission code

20200114104321

Received: 14/01/2020

Revision: 09/09/2020
Accepted: 02/10/2020

OnlineFirst: 21/01/2021

\title{
The Impact of Fix Up Strategy on Indonesian EFL Learners' Reading Comprehension
}

\section{Mohammad Muhassin}

Assoc. Prof., corresponding author, Faculty of Education and Teacher Training, Universitas Islam Negeri Raden Intan Lampung, Indonesia, mohammadmuhasin@ radenintan.ac.id

\section{Jihan Annisa}

Department of English Education, Faculty of Education and Teacher Training, Universitas Islam Negeri Raden Intan Lampung, Indonesia, annisajihan51 @ gmail.com

\section{Dewi Ayu Hidayati}

Department of Sociology, Faculty of Social and Political Sciences, Universitas Lampung, Indonesia, dewiayu.hidayati@fisip.unila.ac.id
This study investigated the impact of using Fix Up Strategy as a specific treatment to deal with the learners' problem in reading that cannot be overcome merely by general reading comprehension course. This was a kind of quasi-experimental research involving 69 students of Madrasah Tsanawiyah (MTs) Al-Hikmah Bandar Lampung, Indonesia. They were divided into two groups: 36 students of experimental group and 33 students of control group. Learners in experimental group were taught with Fix Up Strategy (FUS) and those in the control group were taught with Reading Aloud (RA), a conventional reading activity. The instrument consisted of 25 multiple choice questions that had been previously validated in the procedures of data collection. Then the instrument was given in pre-test and post- test. In addition, observations were also carried out in the process of teaching reading by using FUS. The data were analysed using t-test and the result showed that 1) the students in the treatment with FUS demonstrated a significant improvement in EFL reading comprehension, and 2) FUS contributed to the students' autonomy in learning reading, enhancement of students' awareness in reading, students' active involvement in reading practice. The finding claims that the students who practiced reading with FUS had a better comprehension than those with RA. Certain pedagogical implications related to the finding were also discussed.

Keywords: EFL, learners, reading practice, fix up strategy, experimental group

\section{INTRODUCTION}

In the twenty first century, students' success is influenced by reading comprehension skill (Kissau \& Hiller, 2013). This offers a great challenge for students throughout the

Citation: Muhassin, M., Annisa, J., \& Hidayati, D. A. (2021). The Impact of Fix Up Strategy on Indonesian EFL Learners' Reading Comprehension. International Journal of Instruction, 14(2), 253270. https://doi.org/10.29333/iji.2021.14215a 
world to increase the ability to grasp what they are reading. It is an essential skill to gain a significant progress of learning. In reading procedure, the students should grasp the content of the passage. They must master this perusal skill and the focus is not learning to read, but reading to learn (Alyousef, 2006). During reading practice, reading comprehension is very critical because it encompasses more than reader-to-text answers (Pourhosein Gilakjani \& Sabouri, 2016). It means that the students are unable to obtain knowledge from the reading stuff through reading comprehension. It is a phase of discover meanings of the passage, which is very necessary in reading practice.

In Indonesia setting, many students still confront some difficulties in reading comprehension as Indonesians are more inclined to teach and learn English as a foreign language (EFL) (Sulistiyo, 2016). The activity of teaching-learning English takes place mainly in classrooms, not in everyday communication (Davoudi \& Yousefi, 2015). Apparently, problems in EFL reading comprehension among Indonesian students are lack of vocabulary and prior knowledge, insufficiency of grammar mastery, and poor reading strategies (Setiyadi, 2016).

Referring to a study of The Worlds Most Literate Nations conducted by Central of Connecticut State University, Indonesia is ranked sixtieth from sixty one Southeast Asian countries on reading interest (Miller \& McKenna, 2016). This phenomenon describes the factual condition of Indonesians' reading interest that is on severe crisis, especially among the students. The comprehension of reading text is very important in language learning. Indonesian learners may not find difficulties to understand texts in Indonesian language as reading material, but things will be more complicated when they read English texts (Setiyadi, 2016). Many EFL learners find difficulties in comprehending English texts because they do not master the English vocabulary (Suryanto, 2017). Besides vocabulary shortage, they are also bored with the teachers' conventional strategy and this makes them less motivated in learning reading (Pradana, 2017).

Regarding this problem, the circumstance of teaching-learning activity should be interesting to give learners motive in developing reading comprehension. It is suggested that teachers utilize a specific technique or strategy to enhance the learners' reading comprehension (Sholeh et al., 2019). Some kinds of reading strategy that teachers can use are available; one of them is Fix Up Strategy, henceforth FUS. Students and teachers can employ FUS for collaborative reading to increase students' participation in reading classes and help them comprehend the text individually (Moreillon, 2007).

FUS is a technique that will guide students develop the comprehension of reading materials. When the students get confused with certain terms or certain phrases, fix up strategy will help them comprehend the text message. Students can use this technique to re-read context or figure out the missing terms (Duffy, 2009). This means that a phase to discover the message of the text is to fix up strategy. The technique can help students interpret and discover the difficult words which makes students easier to pace the process of reading comprehension (Fitrisia et al., 2015). The teacher should first clarify the methods for implementing this strategy to students so that they can use it in the 
phase of reading comprehension (Amelia, 2018). As a reference to utilizing the strategy, the teacher will inform learners the task to use it appropriately.

Further Moreillon (2007) points out that in reading comprehension, curiosityexpressing activities are questioning, predicting, and inferring. This implies that the instructor should trigger learners' curiosity to make the experience of reading activity effective. Fix up strategy is the right one since it will transform students into autonomous learners and will also make students more involved as they conceive of the text they are reading on the basis of their experience or mind (Bremer et al., 2002). The procedures that can be used are: (1) re-reading the text (2) interacting with background knowledge, (3) inferencing, (4) forecasting (5) recalling what we have already read in writing (6) visualizing, (7) posing a new question (Moreillon, 2007). Further Tovani (2000) maintains that using Fix Up Strategy in general has some advantages, for instance tracking students' comprehension of the language, and enhancing students' awareness of reading.

The empirical studies above present the importance of applying FUS in teaching reading because of many benefits gained by students toward their reading skill enhancement. Moreover, in a reading crisis situation like now, the application of FUS in teaching EFL reading becomes urgent as one of the reading strategies that attracts students' attention so that the learning situation is not boring and monotonous. Therefore the present study seeks to explore the benefits gained by students when teachers apply FUS in the context of teaching reading comprehension in Indonesia, especially for the eighth grade EFL learners with descriptive text material in line with the school's curriculum and syllabus.

This study assumes that by adapting and practising FUS, some difficulties confronted by students in EFL reading comprehension such as lack of vocabulary and background knowledge, learning dependence, and less engagement in reading practice can be overcome (Davoudi \& Yousefi, 2015). Besides, FUS is expected to cope with the problem concerning the poor strategy used by EFL teachers in teaching activity due to its strong emphasis on the students' active and creative engagement in reading practice within pairs or small groups (Pradana, 2017; Sholeh et al, 2019). It is highly expected that the practice of this reading strategy will be beneficial for students since in FUS, students must play a dynamic and autonomous roles in finding the problems of vocabulary and background knowledge (Moreillon, 2007). FUS can be implemented by rereading, using prior knowledge, thinking, and reflecting as well as solving the problem by visualizing, retelling, and noticing about what was already understood from the text (Indrasari, 2015; Amelia, 2018).

With reference to the scope of the problem, the study is aimed at examining the effectuation and impact of FUS on Indonesian EFL learners' reading comprehension. Particularly, the study tries to respond the problem formulation as follows.

1. How is Fix Up Strategy effectuated in teaching EFL reading comprehension?

2. Does Fix Up Strategy impact significantly on the advancement of the EFL learners' reading comprehension? 


\section{LITERATURE REVIEW}

Teaching English as a Foreign Language (TEFL) in Indonesian schools is a dynamic practice in which not every teacher conducts the same tasks through the same communicative practices (Muhassin, 2016). This argument implies that teaching English skills particularly reading is a conduct that has intertwined components. The teacher should therefore apply an effective approach to teach English so that the learners can actively participate in the phase of teaching-learning (Jose \& Raja, 2011). As a case among Indonesians, learning a native language for example differs from learning a foreign one. It is uneasy to instruct EFL since the instructor needs to explain a language that learners do not practice in daily life (Alwasilah, 2013). The instructor should have an immersive or fascinating system or methodology while teaching English (Nejad \& Keshavarzi, 2015). Therefore innovative strategies or techniques in this situation should be implemented to make the students more interested (Pradana, 2017).

Reading is the method of evaluating, organizing and understanding the multitude of information sources (Scanlon et al., 2010). Reading is uneasy thing because when we read a text, we need a concentration. Reading cannot merely be seen as looking at and remembering any paragraph of a book (Berridge, 2015). In this phase, we also need analysis skills in the reading process to get the details from the document that we interpret. We need to recognize the important thing in the process of reading.

Reading comprehension makes sense when integrating a sort of complicated mechanisms including vocabulary, word awareness, and eloquence (Soleimani \& Hajghani, 2013). Good readers can identify and understand the text which they read. The reader who is unable to interpret well will not grasp the text they are reading without supporting from others. Reading awareness encompasses more than readers' reactions to text (Klingner et al., 2007). This concerns on the readers as well as the document they are processing. Nevertheless, it is not only a question of context, but also in the steps of reading comprehension. Readers are experienced when they grasp the nature of text and utilize their insight to understand the essence or intent of the text that they interpret (Takallou, 2011). Without this kind of ability to understand and communicate with language, the message may fail (Pourhosein Gilakjani \& Sabouri, 2016).

Furthermore, readers need to learn five abilities of reading comprehension to make them easy to read. Those include activating word senses, comprehending sentences, inferencing, monitoring comprehension, and understanding text structure (Moreillon, 2007). In addition to reading comprehension abilities, there are also several strategies of reading comprehension in teaching reading: (1) setting out or constructing information scope, (2) utilizing visual stimuli, (3) asking, (4) predicting and drawing conclusions, (5) defining key points, (6) using fix up options, and (7) reconstructing (Soleimani \& Hajghani, 2013)

Reading strategy, one of language learning strategies, is characterized as a mental behavior strategy to attain a reading objective (Bimmel et al., 2001). These are often known as the mental activities comprehension that the readers choose and implement to 
understand what they are reading (Abbott, 2006). If reading strategies are used appropriately and variedly, they will make a beneficial contribution to the learning process (Grabe, 2009). Most of the readers utilize a variety of methods to collect, retain and restore information (Mikulecky, 2008). Readers may face some difficulties in understanding and apply some strategies to resolve their difficulties (Peregoy \& Boyle, 2001). Each individual profits from diverse strategies and some of them contribute to a quicker and more well-defined comprehension target (Tercanlıglu, 2004).

Considering the significance of reading strategies to overcome students' problems, many studies have been completed concerning instructional guidance of strategy, especially those which are closely related to the application of fix up strategy for Indonesian EFL learners' reading skill. For example, Suryati (2013) investigated the influence of applying fix up strategy on reading comprehension of the eleventh grade learners at SMAN 2 Tapung Kampar Regency applying quasi-experimental design. The study chose 51 senior high school students as research subject divided into 25 students of control class and 26 students of experimental class. The instrument was reading test comprising 25 valid items of multiple choice. The findings exhibited a significant influence of fix up strategy towards students' reading score. It could be found that the t-test was 2.93 greater than 2.01 of $\mathrm{t}$-table on the level of significance $5 \%$ and 2.68 of t-table on $1 \%$ level of significance and the increase on students' mean score from 50.31 in pre-test to 68.92 in post-test.

Another slightly different study, Indrasari (2015) examined the effectiveness of fix up strategy in teaching reading observed from the eighth grade students' self-assurance at SMPN 2 Temanggung. The study selected 52 junior high school students as research subject; 26 students of control group and 26 students of experimental group. The instruments were reading comprehension test and questionnaire. The study came up with some findings as follows: fix up strategy was more effective than direct teaching; the student accomplishment in reading skill did not rely on the level of students' selfassurance; there was no interrelation between teaching strategies and students' selfassurance in teaching reading.

With the selection of different group designs, Kusumawati (2019) carried out an investigation on the impact of fix up strategy on the eleventh grade students' reading comprehension at SMAN 7 Kediri employing experimental design. There was only one group for pre-test and post-test design including 34 students as research subject. The instrument was reading comprehension test. The study reported findings that there was an increase on students' mean score from 65.15 in pre-test to 78.9 in post-test and the t-test was 7.359 greater than 2.034 of t-table. Pertaining to the findings, it could be argued that fix up strategy was efficacious used in teaching reading.

Given the study on higher level students, Suhermanto (2019) questioned whether there was any influence of fix up strategy on students' reading comprehension at Islamic State Institute of Curup applying quasi-experimental design. This was a single group design comprising 60 second semester students of English department as research subject. The instrument was reading comprehension test consisting of 30 valid option test items for pre- and post-tests. The result indicated that the t-count value was 3.905 greater than $\mathrm{t}-$ 
table value, promoting a significant influence of fix up strategy on students' reading comprehension. Besides, there was a considerable divergence of students' mark after being taught employing fix up strategy.

More recently, Farmadani (2019) conducted a study exploring the impact of fix up strategy on the eighth grade students' reading comprehension at SMPN 1 Sumbergempol Tulungagung applying pre-experimental design. This was a group pre-test and post-test design, including 32 students as the subject of research. The instrument was reading comprehension test. The finding indicated that there was a considerable increase on students' mean score from 68.91 in pre-test to 89.06 in post-test and the t-test showed that P-value (Sig.) was 0.000 less than 0.05 , signifying the students' different achievement before and after being instructed employing fix up strategy. Referring to the findings, it could be observed that fix up strategy was effective for teaching reading in junior high school.

The discussion on the previous studies has come to a conclusion that there are different points of view related to the subject level, research type, group design, and research instrument, even though using the same fix up strategy. The present study employs the same strategy but principally finds gaps and tries to fill them with different schemes, namely using quasi-experimental design at junior high school level with 2 group designs, involving two research instruments: reading test and observation. Thus this study attempts to explore the implementation of fix up strategy on Indonesian EFL students' reading comprehension in different perspectives.

\section{METHOD}

\section{Research Design}

This study applied experimental research. This was the only type of study that explicitly tried to affect a specific variable and could be the best type to evaluate theories regarding cause-and-effect interactions when this type was well implemented (Fraenkel et al., 2011; Klassen et al., 2012). Experimental research is systematic research to control over conditions. This type of research is very important, because it can show whether a variable influences another variable or not. Thus, in this study Fix Up Strategy was treated as independent variable $(\mathrm{X})$ and reading comprehension as dependent variable $(\mathrm{Y})$.

Specifically this study applied quasi-experimental design that included a group distribution of participants (Shih \& Reynolds, 2018). The scope of this study was pretest and post-test design to find out the students' reading comprehension of descriptive text by students utilizing Fix-Up Strategy. The research design is shown in table 1.

Table 1

Research design

\begin{tabular}{llll}
\hline Control group & Pre-test & Reading Aloud & Post-test \\
\hline Experimental group & Pre-test & Fix Up Strategy & Post-test \\
\hline
\end{tabular}

In this step, two groups were randomly selected; those were control group and experimental group. Before treatment, the learners were provided with pre-test to 
evaluate the basic reading comprehension. The researcher then applied a treatment for each group, using a conventional reading activity in the control group and Fix Up Strategy in the experimental group. There were three meetings for treatment. Particularly, the experiment of teaching EFL reading using Fix Up Strategy confirmed the procedures suggested by Moreillon (2007) as follows: 1) re-reading the text 2) interacting with prior knowledge, 3) inferencing, 4) forecasting 5) recalling what we have already read in writing 6) visualizing, 7) posing a new question. In the final stage of experimentation, students were handed with post-test to evaluate whether there was a significant difference of students' reading comprehension score after intervention.

\section{Participants}

The study selected the research subject from the eighth grade students of MTs AlHikmah Bandar Lampung, an Islamic Junior High School in Lampung, Indonesia. They have already taken reading comprehension lesson in English subject in line with the school curriculum and syllabus. There were four classes for eight grade: VIIIA, VIIIB, VIIIC, and VIID. Two classes which were of the same kind in their English competence were chosen randomly using lottery. The selected classes were class of VIIIA with 36 students regarded as experimental group and class of VIIID with 33 students regarded as control group. The experimental group was taught by one of the researchers utilizing Fix Up Strategy (FUS) as suggested by Moreillon (2007) and the control group was instructed by a classroom teacher applying Reading Aloud (RA), a conventional reading activity introduced by Ledger \& Merga (2018).

\section{Instruments}

As the instrument data collection, the study applied reading comprehension test with multiple choice questions, comprising two categories of test, Pre-test and Post-test. The Pre-test was given before treatment of the techniques for both groups to assess students' basic reading comprehension and the Post-test was administered to find out the differences of students' reading comprehension after the intervention. The reading texts were based on descriptive genre adopted from the text book of Grade VIII and internet. The researchers developed a reading comprehension test by confirming validity and reliability as the parameter of a proper test proposed by Bordens \& Abbott (2018). Therefore, before distributing the test, the researchers had tried out 50 test items for both pre-test and post-test to another class (VIIIB). The analysis of validity and reliability of the try out resulted in 25 test items which were then distributed in the tests for each group. Table 2 portrayed the blueprint of test points in line with the eight aspects particularly employed to assess reading comprehension as asserted by Brown (2007). 
Table 2

Pre-test and post-test design

\begin{tabular}{lllll}
\hline Aspects & Test Items & & \\
\hline & Pre-test & $\mathrm{N}$ & Post-test & $\mathrm{N}$ \\
\hline Main idea (topic) & $2,5,11,14$ & 4 & $1,11,12,13,18,23$ & 6 \\
Expression/idiom/phrase in context & - & - & 24 & 1 \\
Inference (implied detail) & $7,8,17$ & 3 & 8,17 & 2 \\
Grammatical features & $6,15,19$ & 3 & $5,10,25$ & 3 \\
Detail (scanning for a specially stated detail) & $1,9,10,16$ & & $2,6,7,9,14$ & \\
& $18,21,22,23,24$ & 9 & $15,20,21,22$ & 9 \\
Excluding facts not written & 12 & 1 & 16 & 1 \\
Supporting idea & - & - & - & - \\
Vocabulary in context & $3,4,13,20,25$ & 5 & $3,4,19$ & 3 \\
\hline Total & \multicolumn{3}{l}{25} & 25 \\
\hline
\end{tabular}

Besides, observation with reference to Project-Based Learning (Widiyoko, 2012) was carried out during three meetings of treatment to evaluate the effectuation level of fix up strategy in teaching-learning EFL reading. The observation form comprised 7 statements on the procedures of fix up strategies with "Yes" or "No". Then the observation result could be interpreted using the following criteria.

Table 3

Criteria of fix up strategy effectuation

\begin{tabular}{ll}
\hline Criteria & Percentage \\
\hline Very good & $80-100$ \\
Good & $60-80$ \\
Fair & $40-60$ \\
Poor & $20-40$ \\
Fail & $0-20$ \\
\hline
\end{tabular}

(Widiyoko, 2012)

\section{Data Analysis}

The study employed statistical computation including normality test and homogeneity test in analysing data. Then, t-test for two correlated samples was also utilized to find out the substantial divergence between the pre-test and post-test grades of students who were taught using FUS and those who were not. For practicality and efficiency of the study, statistical computation of SPSS was also applied for hypothesis test. In addition, the followings were the indicators of hypothesis adoption and ejection. Ha was accepted if Sig. $<\alpha=0.05$ and H0 was admitted if Sig. $>\alpha=0.05$.

\section{FINDINGS}

\section{Implementation of Fix Up Strategy in Reading Comprehension}

Data on the implementation of FUS procedures in teaching reading comprehension came from recapitulation of observation in three meetings of treatment in experimental group. Table presents 4 the result of observation. 
Table 4

Frequency on the implementation of fix up strategy

\begin{tabular}{lllll}
\hline Indicators & \multicolumn{2}{c}{ Yes } & \multicolumn{2}{c}{ No } \\
\cline { 2 - 5 } & $\mathrm{N}$ & $\%$ & $\mathrm{~N}$ & $\%$ \\
\hline $\begin{array}{l}\text { Teacher involves students to read and let them state the problems } \\
\text { encountered. }\end{array}$ & 3 & 100 & 0 & 0 \\
$\begin{array}{l}\text { Teacher asks students to stop in the words considered insensible. } \\
\text { Teacher commands students to puzzle out and let them utilize the look- }\end{array}$ & 2 & 66.7 & 1 & 33.3 \\
$\begin{array}{l}\text { back } \\
\text { or fix up strategy. }\end{array}$ & 3 & 100 & 0 & 0 \\
$\begin{array}{l}\text { Teacher apprises students to detect the problem (unknown words) and to } \\
\text { think if they if they know anything about the problem and aids them to }\end{array}$ & 2 & 66.7 & 1 & 33.3 \\
$\begin{array}{l}\text { dissolve it. } \\
\text { Teacher urges students to utilize context clues. }\end{array}$ & 2 & 66.7 & 1 & 33.3 \\
Teacher lets students prove if the words are intelligible or not. & 3 & 100 & 0 & 0 \\
$\begin{array}{l}\text { Students can proceed reading and conduct the fix- up strategy if they } \\
\text { encounter more problems. }\end{array}$ & 3 & 100 & 0 & 0 \\
Total & 18 & 85.7 & 3 & 14.3 \\
& & & &
\end{tabular}

Table 4 manifests the level of implementation of FUS procedures in teaching reading comprehension. The frequency of "Yes" answer is 18 or $85.7 \%$, whereas the frequency of "No" answer is 3 or $14.3 \%$. Referring to the scoring criteria in table 3, it can be interpreted that the implementation of FUS is on the level of "very good". Thus, we come to a conclusion that FUS has already been practiced properly as a strategy used to improve students' reading comprehension.

\section{Result of Reading Comprehension Test}

\section{Result of Pre-test}

Pre-test in control group was executed on September 16, 2019 prior to the intervention given to the students to assess their basic reading comprehension in descriptive text, as shown in Figure 1.

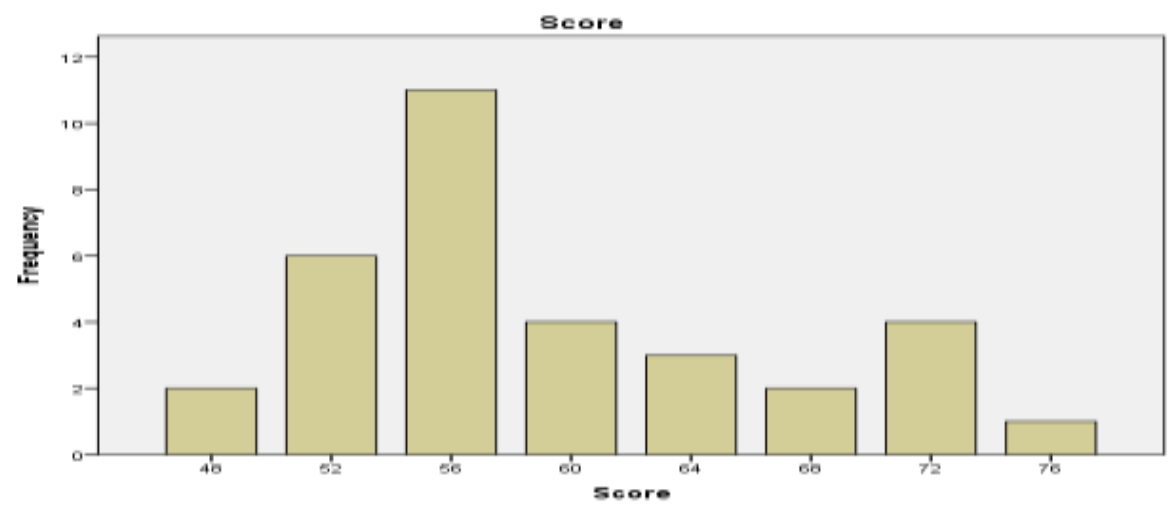

Figure 1

Pre-test result of control group 
Figure 1 displays that the learners' reading comprehension score is regarded low, with the mean value of 59,27 for pre-test. The scores are 48 for 2 students; 52 for 6 students; 56 for 11 students; 60 for 4 students; 64 for 3 students; 68 for 2 students; 72 for 4 students; 76 for 1 student. The lowest grade is 48 and the highest one is 76 .

Then the pre-test was also put in practice for the experimental group on September 16, 2019. The result is drawn in Figure 2.

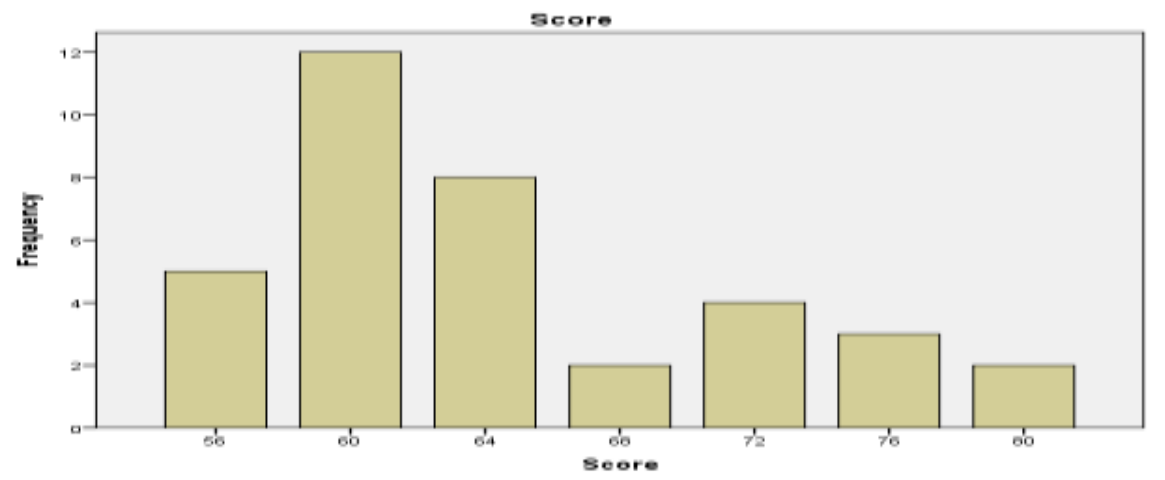

Figure 2

Pre-test result of experimental group

Figure 2 indicates that the mean value of pre-test is 64.56 . The scores are 56 for 5 students; 60 for 12 students; 64 for 8 students; 72 for 4 students; 76 for 3 students; 80 for 2 students. 56 is the lowest score and 80 is the highest one.

\section{Results of Post-test}

The post-test was conducted to search for the crucial impact on both control and experimental groups after the treatments had been implemented. The control group posttest was issued on 25 September 2019. The ratings of the students' reading comprehension are shown in figure 3.

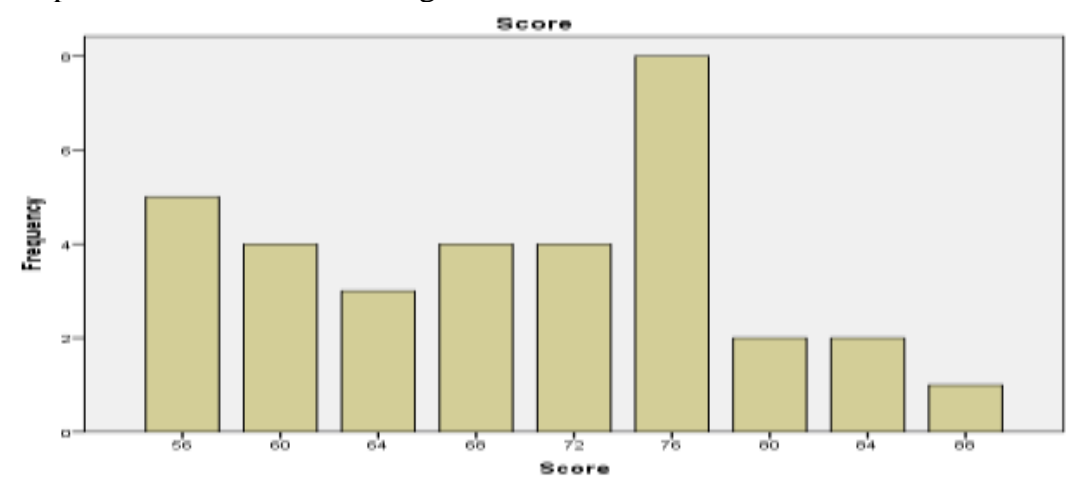

Figure 3

Post-test result of control group 
Figure 3 signals that the control group mean is 69.58 . The scores are 56 for 5 students; 60 for 4 students; 64 for 3 students; 68 for 4 students; 72 for 4 students; 76 for 8 students; 80 for 2 students; 84 for 2 students; and 88 for 1 student. The lowest grade is 56 and the highest one is 88 .

The post-test was also executed in the experimental group on September 25, 2019 to see the major impact after the treatment. Figure 4 provides the ratings of the post-test.

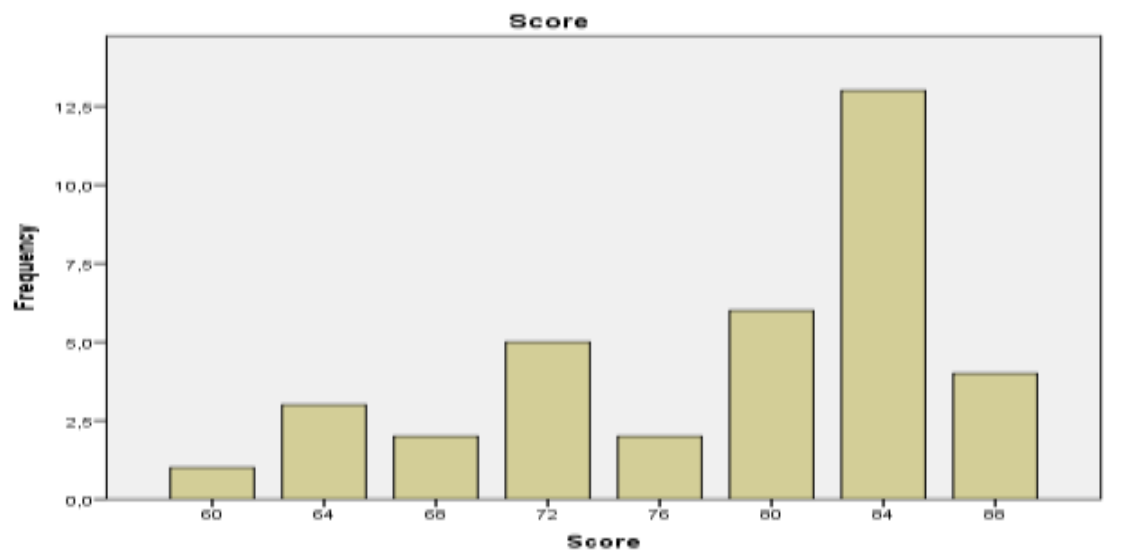

Figure 4

Post-test result of experimental group

Figure 4 presents a significant improvement of students' score after three treatments using fix up strategy. It can be seen that the mean value of post-test in experimental group is 78.44. The scores are 60 for 1 student; 64 for 3 students; 68 for 2 students; 72 for 5 students; 76 for 2 students; 80 for 6 students; 84 for 13 students; and 88 for 4 students. The lowest score is 60 and 88 is the highest.

Table 5

Comparison of pre-test and post-test scores of the experimental and control groups

\begin{tabular}{lllll}
\hline Category & \multicolumn{2}{c}{ Fix Up Strategy } & \multicolumn{2}{c}{ Reading Aloud } \\
\cline { 2 - 5 } & Pre-test & Post-test & Pre-test & Post-test \\
\hline Lowest & 56 & 60 & 48 & 56 \\
Highest & 80 & 88 & 76 & 88 \\
Mean & 64.56 & 78.44 & 59.27 & 69.58 \\
\hline
\end{tabular}

The data presentation in table 5 shows that there has been a good progress on pre-test and post-test scores for control group as well as experimental group. The mean value of the control group from pre-test is 59.27 and the post-test is 69.58. Meanwhile, the mean value of the experimental group pre-test is 64.56 and the post-test is 78.44 . It can be clearly seen that there are changes on both groups. However, the performance of experimental group is greater than the control group. The discussion comes up with a conclusion that there is a significant enhancement of students' reading comprehension score in the experimental group compared to the control group. 
The significant enhancement of reading score in experimental group might have been achieved because of the treatment using Fix Up Strategy, which demanded teacher and learners' engagement. The learners' pos-test proved the significant difference to the pre-test and this is line with the assertion that implementing Fix Up Strategy can improve leraners' reading comprehension skill. This finding corresponds to Suhermanto (2019) who claimed that students taught with Fix Up Strategy exhibited improvement on reading comprehension.

\section{Result of Normality Test}

The test of normality was carried out by applying statistical analysis of SPSS version 20 after obtaining the students' reading comprehension score from the tests. The hypotheses is: the data are normally administered $(\mathrm{H} 0)$ and the data are not normally allotted (Ha). $\mathrm{H} 0$ is accepted if sig. (p) $>\alpha=0.05$, and Ha is valid if sig. (p) $<\alpha=0.05$.

Table 6

Normality test

\begin{tabular}{llllllll}
\hline \multirow{2}{*}{ Groups } & \multicolumn{3}{l}{ Kolmogorov-Smirnov $^{\mathrm{a}}$} & \multicolumn{3}{l}{ Saphiro-Wilk } \\
& & Statistic & Df & Sig. & Statistic & Df & Sig. \\
\hline \multirow{3}{*}{ Gain } & Experimental & .131 & 36 & .948 & 36 & .091 \\
& & .121 & & & & \\
& Control & .148 & 33 & .940 & 33 & .068 \\
& & .065 & & & & & \\
\hline
\end{tabular}

a. Lilliefors Significance Correction

Table 6 reveals that the control group's Sig. is 0.068 and the experimental group's Sig. is 0.091 . Both significances are more than 0.05 . Therefore $\mathrm{Ha}$ is refused, and $\mathrm{H}_{0}$ is assumed. This signifies that the data of control and experimental groups are normally administered.

\section{Result of Homogeneity Test}

The test of homogeneity was manifested in both control and experimental groups after gaining the results of pre-test and post-test, by proposing two hypotheses. The data variances were not homogeneous $\left(\mathrm{H}_{\mathrm{a}}\right)$, and the data variances were homogeneous $\left(\mathrm{H}_{0}\right)$ with criteria: $\mathrm{H}_{0}$ was assumed if $\mathrm{Sig}$. $>\alpha=0.05$, and $\mathrm{Ha}$ was considered if Sig. $<\alpha=$ 0.05 .

Table 7

Homogeneity test

\begin{tabular}{llll}
\hline Levene's Statistic & df1 & df2 & Sig. \\
\hline & 1 & 67 & .595 \\
\hline
\end{tabular}

The homogeneity test result in table 7 indicates that the significance is 0.595 , greater than 0.05 . Thus, it can be argued that the test data come from homogenous groups.

\section{Result of Hypothesis Test}

The prior discussion stated that the normality and the homogeneity tests were satisfying. Therefore, the hypothesis test using independent samples t-test was implemented to scrutinize the considerable impact of FUS on the students' reading comprehension. 
Table 8

Independent samples t-test

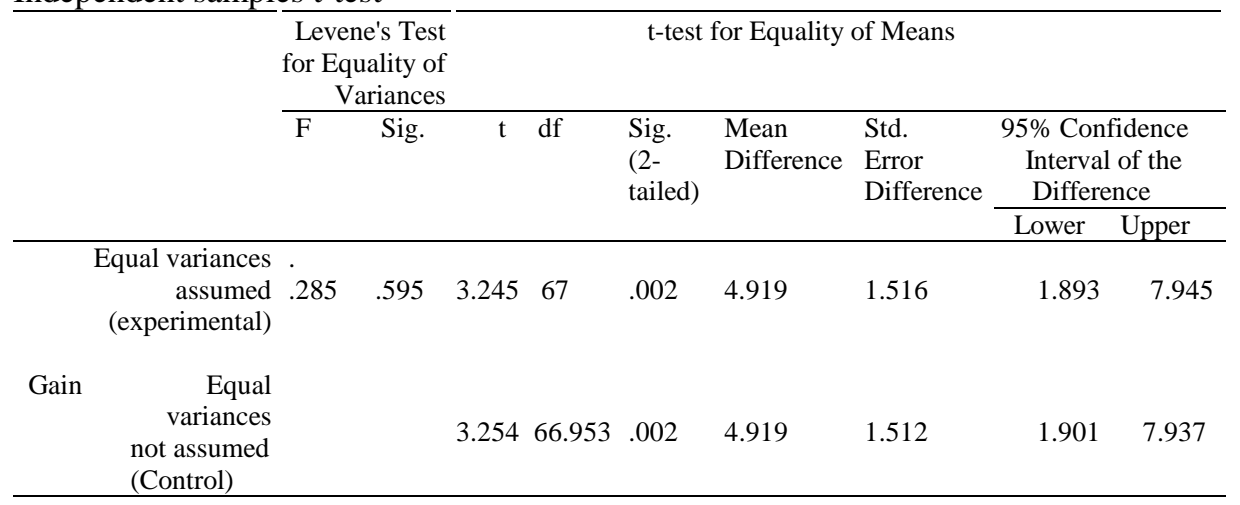

Table 8 indicates that probability (p) value of Sig. (2-tailed) for experimental group is 0.002. Referring to the criteria of Hypothesis test, if sig. value is less than 0.05 , Ha is accepted. It can also be inferred that there is a substantial difference between pre-test and post-test scores in experimental group. The hypothesis test result proves that the implementation of Fix Up Strategy contributes a considerable impact on EFL learners' reading comprehension.

\section{DISCUSSION}

\section{Implementation of FUS}

The primary aim of the study is to delve the relations between the implementation of Fix Up Strategy as a specific treatment in teaching EFL reading comprehension and its impact on the advance of EFL students' reading comprehension. With regard to this objective, this study attempts to explore how a teacher teaches reading using FUS a special treatment to enhance students' reading skill. Direct observations were conducted by researcher in three treatment meetings. The results of observation as shown in table 4 indicated that the frequency of implementation of FUS procedures reached $85.7 \%$ which was categorized as very good level. This achievement has positive implications for students in understanding and practicing FUS in the process of reading comprehension learning. Thus, the main benefit of the study is to alleviate students to be able to enhance their reading skill through the application of the FUS.

The observation results in the treatment process showed that students appeared more engaged in learning reading as the teacher implemented FUS. This might happen because the teacher's instructional guide on the application of the FUS procedure has a good effect on overcoming the problem of students who have limited vocabulary and background knowledge. The result is that applying FUS can help them understand the parts of the English text that are difficult. The teacher's role as a learning facilitator is very important in improving reading skills. This is closely related to the finding of Suhermanto (2019) which states that teacher guidance is needed in order to improve students' learning outcomes for better reading. 
Treatment with FUS has made learning conditions conducive so students can be actively and independently involved in self-monitoring and self-correction when they encountered confusing text. In self-monitoring students were aware when meanings broke down, identified words, phrases, paragraphs they did not understand and used fix strategy to restore the meaning. This is consistent with Indrasari (2015) who maintains that by applying FUS, students were facilitated to be actively engaged in reading text by providing fix-up devices, such as previewing, predicting, rereading, making connection, visualizing, inferencing, and retelling the text. Self-monitor requires metacognitive knowledge, which is understanding when reading makes sense by tracking and monitoring one's own understanding (Takallou, 2011).

One of the factors that FUS can improve student reading comprehension score is efficiency on how to study the course material in a cooperative learning approach which supports involvement and compassion by providing each member of the group an important part to play in the academic performance (Nejad \& Keshavarzi, 2015). Students were given more space to be engaged in reading practice by pointing out their difficulties in comprehending text with their pairs through discussion. Within a small cooperative group, when students find the clunks, i.e. the word, idea, or concept which are uneasy to understand and break down reading comprehension of the whole text, they need to identify the clunks and figure them out using fix-up strategies (Bremer et al., 2002; Sholeh et al., 2019).

\section{Comparison Result of of Pre-Test and Post-test Scores}

The result explanation might be based on the effect of FUS on the reading comprehension of EFL students, which was obtained from the pre-test and post-test results. The assessments that had the same time allocation, material, test design, and set of questions administered to the students in the two groups were assigned to verify whether or not FUS brought advancements to the reading comprehension of EFL learners. The discussion on pre-test and post-test results reveals that there is a substantial gap in the reading comprehension scores of the EFL students. The result of observation shows that the practice of FUS was categorized in a very good level, signifying the enhancement of reading comprehension of EFL learners by promoting conducive learning situation, learning independence, and more students' engagement in reading practice with pair discussion.

The intervention has improved reading comprehension levels for EFL students from 80 to 88 . Therefore, it can be concluded that the intervention might have induced the rise in reading scores. There were clearly substantial differences in the students' post-test scores and this endorses the argument that using FUS will enhance reading comprehension skill. The finding significantly showed that the students' reading scores increased steadily. This finding is compatible with some earlier studies focusing on the use of FUS which has enhanced students' reading comprehension skill. This study also demonstrates that the reading comprehension scores of EFL students increased when the teacher designed reading activities that allowed more space for students to participate in reading practice in groups or pairs, to learn independently and to follow instructional 
guidelines on the reading strategy (Bremer et al., 2002; Indrasari, 2015, Suhermanto, 2019).

\section{CONCLUSION AND RECOMMENDATIONS}

This study has successfully proved that there is a substantial impact of implementing FUS for improving students' reading skill. This is owing to the fact that the implementation of the FUS procedure has facilitated students to be able to understand English text better so that it has positive implications on increasing students' reading comprehension scores. FUS is considered as an efficient and effective reading strategy by promoting learning strategies that are interesting and not monotonous, providing broader opportunities for students to engage actively in group discussions, and guiding students to be independent in seeking and overcoming difficult parts of the English text. The contribution of FUS is very positive for students' understanding of the English text because the mechanism of self- monitor and self-correction is emphasized in FUS practice. Thus, when finding difficulties in the English text section, students can independently overcome these difficulties through a fix up strategy.

At the level of TEFL, by considering the tangible benefits of FUS, it is strongly suggested that English teachers employ this technique in teaching reading comprehension. EFL students' understanding will be better when there is a solution to the problem of limited vocabulary and background knowledge in comprehending the English text. FUS trains students to learn independently and to be actively engaged in group or pair discussions to solve the problem.

This study has limitations in terms of the research subject which was limited to the Indonesian EFL junior high school students and the data collection through tests and observations. Therefore, it is recommended for further research to utilize other levels of schools, such as elementary school, senior high school, and even universities so that they will get more comprehensive study results. In addition, using a questionnaire to determine students' responses to the application of FUS will also make the study more valid.

For education stakeholders particularly for policy makers and for junior level teachers, the findings of this study may be utilized as a guidance for conducting training to develop reading comprehension skills using FUS. The aim is to equip them with teaching techniques that are not monotonous and provide solutions to students' problems in reading comprehension. The application of this technique becomes urgent because it promotes a conducive learning atmosphere, trains students to be more independent in finding solutions to their problems and enlarges student involvement in pair or group discussions which eventually can enhance students' reading comprehension skill.

\section{REFERENCES}

Abbott, M. L. (2006). ESL reading strategies: Differences in Arabic and Mandarin speaker test performance. Language Learning, 56(4), 633-670.

Alwasilah, C. (2013). Policy on foreign language education in Indonesia. International Journal of Education, 7(1), 1-19. 
Alyousef, H. S. (2006). Teaching reading comprehension to ESL/EFL learners. Journal of Language Learning, 5(1), 143-154.

Amelia, L. (2018). Fix Up Strategi untuk Meningkatkan Kemampuan Bahasa Inggris. Puslitbang STAI Al Azhar Pekanbaru, 7, 91-102.

Berridge, G. (2015). Personal Reading Strategies of College Freshmen Placed in a Developmental Reading Class. International Journal of Global Education, 4(3).

Bimmel, P. E., van den Bergh, H., \& Oostdam, R. J. (2001). Effects of strategy training on reading comprehension in first and foreign language. European Journal of Psychology of Education, 16(4), 509-529.

Bordens, K. S. \& Abbott, B. B. (2018). Research design and methods: a process approach (Tenth edition). New York: McGraw-Hill Education.

Bremer, C. D., Vaughn, S., Clapper A.T., \& Kim, A.H. 2002. Collaborative Strategic Reading (CSR): Improving Secondary Studentse Reading Comprehension Skills. National Center on Secondary Education and Transition Services to Practice Brief, 1(2), 1- 8 .

Brown, H. D. (2007). Principles of language learning and teaching (5th ed). White Plains, NY: Pearson Longman.

Davoudi, M., \& Yousefi, D. (2015). Comprehension Breakdown: A Review of Research on EFL Learners' Reading Difficulty and Problems. International Journal of Language and Applied Linguistics, 1, 58-72.

Duffy, G. G. (2009). Explaining reading: A resource for teaching concepts, skills, and strategies. Guilford Press.

Farmadani, M. (2019). The Effectiveness of Fix-Up Strategy towards Reading Comprehension Skill at the Second Grade Of SMPN 1 Sumbergempol (Undergraduate Thesis). Retrieved 12 April 2020 from http://repo.iain-tulungagung.ac.id/12563/

Fitrisia, D., Tan, K. E., \& Yusuf, Y. Q. (2015). Investigating metacognitive awareness of reading strategies to strengthen students' performance in reading comprehension. Asia Pacific Journal of Educators and Education, 30(1), 15-30.

Fraenkel, J. R., Wallen, N. E., \& Hyun, H. H. (2011). How to design and evaluate research in education. New York: McGraw-Hill Humanities/Social Sciences/Languages.

Grabe, W. (2009). Reading in a second language: Moving from theory to practice. New York: Cambridge University Press.

Indrasari, N. (2015). The Effectiveness of Using Fix-Up Strategy to Teach Reading Viewed from Students' Self-confidence. English Education: Jurnal Tadris Bahasa Inggris, 8(1), 55-27. doi:https://doi.org/10.24042/ee-jtbi.v8i1.510. 
Jose, G. R., \& Raja, B. (2011). Teachers' Role in Fostering Reading Skill: Effective and Successful Reading. Journal on English Language Teaching, 1(4), 1-10.

Kissau, S., \& Hiller, F. (2013). Reading Comprehension Strategies: An International Comparison of Teacher Preferences. Research in Comparative and International Education, 8(4), 437-454. https://doi.org/10.2304/rcie.2013.8.4.437.

Klassen, A. C., Creswell, J., Clark, V. L. P., Smith, K. C., \& Meissner, H. I. (2012). Best practices in mixed methods for quality of life research. Quality of Life Research, 21(3), 377-380.

Klingner, J. K., Vaughn, S., \& Boardman, A. (2007). Teaching reading comprehension to students with learning difficulties. New York: Guilford Press.

Ledger, S., \& Merga, M. K. (2018). Reading Aloud: Children's Attitudes toward being Read to at Home and at School. Australian Journal of Teacher Education, 43(3), 124139.

Kusumawati. Y. (2019). The use of fix up strategy in teaching reading comprehension for eleventh grade students at SMAN 7 Kediri (Undergraduate

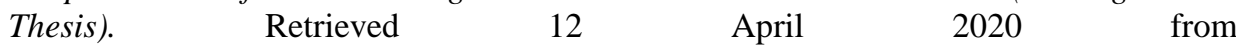
http://simki.unpkediri.ac.id/mahasiswa/file_artikel/2019/14.1.01.08.0029.pdf

Mikulecky, B. S. (2008). Teaching reading in a second language. Retrieved on 10 April 2020, from: http://longmanhomeusa. com.

Miller, J. W., \& McKenna, M. C. (2016). World literacy: How countries rank and why it matters. Routledge.

Moreillon, J. (2007). Collaborative strategies for teaching reading comprehension: Maximizing your impact. Chicago: American Library Association.

Muhassin, M. (2016). Teachers' Communicative Activities in Teaching English as A Foreign Language (Tefl): A Study at Sman 9 Bandar Lampung. Humaniora, 7(4), 485. https://doi.org/10.21512/humaniora.v7i4.3601.

Nejad, S.G. \& Keshavarzi, A. (2015). The Effect of Cooperative Learning on Reading Comprehension and Reading Anxiety of Pre-University Students. Journal of Applied Linguistics and Language Research. 2(8). 169-180.

Peregoy, S. F. \& Boyle, O. F. (2001). Reading, writing, \& learning ESL. New York: Longman.

Pourhosein Gilakjani, A. \& Sabouri, N. (2016). How Can Students Improve Their Reading Comprehension Skill?. Journal of Studies in Education. 6. 229. 10.5296/jse.v6i2.9201.

Pradana, S. A. (2017). The Analysis of Teaching and Learning Reading Through ThinkAloud Method. ELT Echo: The Journal of English Language Teaching in Foreign Language Context, 2(2), 170. https://doi.org/10.24235/eltecho.v2i2.2177. 
Scanlon, D. M., Anderson, K. L., \& Sweeney, J. M. (2010). Early intervention for reading difficulties: The interactive strategies approach. New York: Guilford Press.

Setiyadi, A. (2016). How Successful Learners Employ Learning Strategies in an EFL Setting in the Indonesian Context. English Language Teaching, 9(8), 28-38.

Shih, Y. C., \& Reynolds, B. L. (2018). The effects of integrating goal setting and reading strategy instruction on English reading proficiency and learning motivation: A quasi-experimental study. Applied Linguistics Review, 9(1), 35-62.

Sholeh, A., Setyosari, P., Cahyono, B. Y., \& Suthoni. (2019). Effects of Scaffolded Voluntary Reading on EFL Students' Reading Comprehension. International Journal of Instruction, 12(4), 297-312. https://doi.org/10.29333/iji.2019.12419a.

Soleimani, H., \& Hajghani, S. (2013). The effect of teaching reading comprehension strategies on Iranian EFL pre-university students' reading comprehension ability. International Journal of Applied and Basic Sciences, 5(5), 594-600.

Suhermanto, H. 2019. The Effect of Fix Up Strategy in Enhancing Students Reading Comprehension in IAIN Curup. English Franca: Academic Journal of English Language and Education, 3(1), 1-14.

Sulistiyo, U. (2016). English language teaching and Efl teacher competence in Indonesia. Proceedings of ISELT FBS Universitas Negeri Padang, 4(2), 396-406.

Suryanto, S. (2017). An Investigation on English Reading Comprehension Problems in Indonesian Cultural Contexts. International Conference on Education, Science, Art and Technology, 0, 200-205. Retrieved 5 January from http://ojs.unm.ac.id/icesat/article/view/3738.

Suryati. (2013). The effect of using fix up strategy towards reading comprehension of the second year students at SMAN 2 Tapung Kampar Regency (Undergraduate Thesis). Retrieved 12 April 2020 from http://repository.uin-suska.ac.id/10081/1/2013_20131057PBI.pdf

Takallou, F. (2011). The Effect of Metacognitive Strategy Instruction on EFL Learners' Reading Comprehension Performance and Metacognitive Awareness. Asian EFL Journal, 13(1). 26-34.

Tercanlioglu, L. (2004). Postgraduate students' use of reading strategies in L1 and ESL contexts: Link to su ccess. International Education Journal, 5(4), 89-110.

Tovani, C. (2000). I read it, but I don't get it. Colorado: Stenhouse Publishers.

Widoyoko, E. P. (2012). Teknik Penyusunan Instrumen Penelitian. Yogyakarta: Pustaka Pelajar. 